\title{
Il Pellegrinaggio in Oriente di Henry Corbin, Con una scelta di testi. Lavis (Trento, Italia), La Finestra, 2003, 432 p., E. 42.
}

\section{Pierre Lory}

\section{(2) OpenEdition}

Journals

Édition électronique

URL : http://journals.openedition.org/abstractairanica/12862

DOI : 10.4000/abstractairanica.12862

ISSN : 1961-960X

Éditeur :

CNRS (UMR 7528 Mondes iraniens et indiens), Éditions de l'IFRI

\section{Édition imprimée}

Date de publication : 15 mai 2007

ISSN : 0240-8910

Référence électronique

Pierre Lory, « II Pellegrinaggio in Oriente di Henry Corbin, Con una scelta di testi. Lavis (Trento, Italia), La Finestra, 2003, 432 p., E. 42. », Abstracta Iranica [En ligne], Volume 28 | 2007, document 278, mis en ligne le 18 septembre 2007, consulté le 25 septembre 2020. URL : http://journals.openedition.org/ abstractairanica/12862 ; DOI : https://doi.org/10.4000/abstractairanica.12862

Ce document a été généré automatiquement le 25 septembre 2020.

Tous droits réservés 


\section{Il Pellegrinaggio in Oriente di Henry Corbin, Con una scelta di testi. Lavis (Trento, Italia), La Finestra, 2003, 432 p., E. 42.}

Pierre Lory

1 Il s'agit d'un volume de six essais consacrés aux enjeux des concepts mis en lumière et défendus par Henry Corbin dans une optique de philosophie et de spiritualité comparées. G.G. est à la recherche de nouveaux paradigmes philosophiques qui pourraient rendre compte à la fois de la cosmologie issue de la science contemporaine, de la pensée extrême orientale, le tout dans le cadre d'une approche européenne. Il est à noter que sa réflexion s'est poursuivie dans un second volume, Nitarta - Saggi per un pesiero eurasiatico (2004), où les thèmes corbiniens sont également présents.

INDEX

Thèmes : 8 . Soufisme

\section{AUTEURS}

PIERRE LORY

EPHE - Paris 